\title{
PERSEPSI TERHADAP POLA ASUH ORANG TUA DAN SIKAP TERHADAP PERILAKU SEKSUAL PRANIKAH SISWA/I SMAN $X$ MANADO
}

\section{The Perception of Parenting Style and Attitude Towards Premarital Sexual Behavior of Students in SMAN X Manado}

\author{
Marisstella Meira Menggasa \\ Program Studi Psikologi Universitas Bunda Mulia
}

Diterima 6 April 2020/ Disetujui 22 Mei 2020

\begin{abstract}
The amount of increasing premarital sexual behavior causing the undesirable pregnancy to the teenagers. Thus, parents' role through parenting is required to shape and direct the teenagers attitude in terms of reducing premarital sexual behavior. Parenting patterns could be appreciated either positive or negative by teenagers. Parenting might used by parents to prevent teenager in a risky behavior like premarital sexual behavior. This study aiming to see the relationship between parenting perception with attitude toward premarital sexual behavior in SMA N 2 Manado. This study is correlational study. Populations in this study amount 600 students. Within 220 students as samples, and the sample collection was the purposive sample. The research instrument in this study is questionnaire. The result indicate that perception of authoritarian parenting has no relationship toward premarital sexual behavior with value $p=0,135>0,05$, similar with perception of authoritative parenting which has no relationship with an attitude toward premarital sexual behavior with value $p=0,301>0,05$. Where as for perception of neglectful parenting has a significant relationship with an attitude toward premarital sexual behavior with value $p=0,000<0,01$ and same with perception of indulge permissive has a significant relationship with an attitude toward premarital sexual behavior with value $p=0,001<0,01$.
\end{abstract}

Keyword: Perception toward parenting style, attitude, premarital sexual behavior, students

\begin{abstract}
ABSTRAK
Jumlah perilaku seksual pranikah yang meningkat menyebabkan terjadinya peningkatan kehamilan yang tidak diinginkan pada remaja. Sehingga peran orangtua lewat pola asuh diperlukan untuk membentuk dan mengarahkan sikap remaja terhadap perilaku seksual pranikah. Pola asuh orang tua dapat dipersepsi secara positif dan negatif oleh remaja. Tujuan dalam penelitian ini untuk melihat hubungan antara persepsi pola asuh orang tua dengan sikap terhadap perilaku seksual pranikah pada remaja di SMAN X Manado. Jumlah sampel penelitian sebanyak 220 partisipan dengan teknik pengambilan sampel purposive sampling. Jenis penelitian ini adalah penelitian korelasional. Alat ukur dalam penelitian ini menggunakan kuesioner persepsi pola asuh orangtua yang dibuat berdasarkan teori pola asuh orangtua yang terbagi menjadi pola asuh otorites, autoritatif dan permisif. Alat ukur skala sikap dibuat berdasarkan komponen sikap yaitu: kognitif, afektif dan konatif. Hasil menunjukan bahwa persepsi pola asuh otoriter tidak memiliki hubungan dengan sikap terhadap perilaku seksual pranikah dengan nilai $p=0,153>0,05$, begitupula persepsi pola asuh autoritatif yang tidak memiliki hubungan dengan sikap terhadap perilaku seksual pranikah dengan nilai $\mathrm{p}=0,301>0,05$. Sedangkan untuk persepsi pola asuh permisif mengabaikan memiliki hubungan yang signifikan dengan sikap terhdap perilaku seksual pranikah dengan nilai $\mathrm{p}=0,000<0,01$ dan persepsi pola asuh permisif memanjakan juga memiliki hubungan yang signifikan dengan sikap terhdap perilaku seksual pranikah dengan nilai $\mathrm{p}=0,001<0,01$.
\end{abstract}

Kata kunci: persepsi pola asuh orangtua, sikap, perilaku seksual pranikah, siswa-siswi

\footnotetext{
*Korespondensi Penulis:

menggasamarisstella@yahoo.com
} 
Versi Online: http://journal.ubm.ac.id/index.php/psibernetika DOI: 10.30813/psibernetika.v13i1.2314 Hasil Penelitian

\section{PENDAHULUAN}

Masa remaja merupakan masa peralihan, karena periode ini terjadi banyak perubahan yang berbeda dari masa kanakkanak menuju dewasa. Masa remaja memberikan kesempatan untuk bertumbuh dan berkembang tidak hanya dalam dimensi fisik, tetapi juga dalam kompetensi kognitif, sosial, otonomi, harga diri, dan keintiman (Papalia, Olds,\& Feldman, 2008). Usia remaja menurut World Health Organization (WHO) adalah penduduk dalam rentang usia 10-19 tahun. Jumlah kelompok remaja dengan usia 10-19 tahun di Indonesia menurut Sensus Penduduk 2010 sebanyak 43,5 juta atau sekitar $18 \%$ dari jumlah penduduk (Infodatin Kemenkes RI, 2016). Jumlah kelompok usia remaja yang lebih besar dari pada kelompok usia lain ditunjukkan dari piramida penduduk Indonesia pada tahun 2012 yang berbentuk expansive (Putri, 2014). Tingginya jumlah pertumbuhan remaja di sisi lain menjadi perhatian, karena pada usia ini mereka rentan terhadap masalah-masalah dan menghadapi risiko akibat perubahan yang dialami mereka. Sehingga mereka memerlukan bantuan untuk menghadapi bahaya perubahan yang mungkin terjadi di masa ini (Papalia, Olds, \& Feldman, 2008).

Pada tahap ini orang tua harus berhati-hati dan seimbang dalam memberikan kesempatan untuk mandiri kepada remaja dan melindungi remaja dari kegagalan karena faktor belum siap secara mental. Hal ini disebabkan karena sikap dan perilaku orang tua tidak hanya memiliki pengaruh yang kuat pada hubungan di dalam keluarga, tetapi juga memiliki pengaruh kepada sikap dan perilaku anak (Hurlock, 2000). Sikap dan perilaku orang tua yang disebut pola asuh menjadi faktor penting dalam kehidupan remaja. Pola asuh orang tua adalah gambaran tentang sikap dan perilaku orang tua dengan anak dalam berinteraksi, serta berkomunikasi selama mengadakan kegiatan pengasuhan (Monks, dkk, 2007; dalam Safitri \& Hidayati,2013). Dengan interaksi dan komunikasi dalam pola asuh orang tua memiliki dampak
Jurnal Psibernetika

Vol.13 (No.1) : 32 -42. Th. 2020

p-ISSN: 1979-3707

e-ISSN: 2581-0871

dalam kehidupan para remaja. Hal ini disebabkan karena orang tua merupakan guru yang pertama dan terbaik dalam mengajar anak mereka dan dalam pembentukan karakter anak (Fataruba dkk, 2009).

Pola asuh orang tua juga merupakan pola perilaku yang diterapkan pada anak dan bersifat relatif konsisten dari waktu ke waktu. Pola perilaku ini dapat dirasakan oleh anak, dari segi negatif maupun positif (Monks, dkk, 2007; dalam Safitri \& Hidayati, 2013). Pola asuh yang dirasakan oleh anak menyebabkan munculnya penilaian terhadap pola asuh orang tua, apakah perlakuan orang tua tersebut positif atau negatif tergantung dari bagaimana anak mempersepsikan pola asuh yang diberikan oleh orang tua. Persepsi pola asuh orang tua adalah proses dimana individu mengenali, mengorganisasi, dan menginterpretasi cara orang tua mendidik, membimbing, dan melindungi individu tersebut agar sesuai dengan norma yang berlaku dalam masyarakat (Wulaningsih \& Hartini, 2015). Menurut Papalia dan Feldman (2012), menjelaskan gambaran jenis pola asuh orangtua: Pola asuh Autoritatif (Authoritative) adalah orang tua yang menghargai individualitas anak tetapi juga menekan batasan-batasan sosial. Mereka percaya akan kemampuan mereka dalam mengasuh anak, tetapi juga menghargai keputusan mandiri, minat, pendapat, dan kepribadian anak; 2) Pola Asuh Autoritarian (Authoritarian) yaitu orang tua yang memiliki kontrol yang tinggi pada anak-anak mereka dan menuntut kepatuhan dari anak-anak mereka. Mereka akan berusaha untuk membuat anak mematuhi setiap standar perilaku yang mereka tentukan dan akan menghukum secara tegas jika terdapat pelanggaran yang dibuat oleh anak-anak mereka. Orang tua yang otoritarian cenderung kurang memiliki kehangatan pada anak-anak mereka; 3) Pola Asuh Permisif (Permissive) yang mana orang tua menghargai ekspresi diri dan pengaturan diri. Mereka hanya membuat sedikit permintaan dan membiarkan anak 
Versi Online: http://journal.ubm.ac.id/index.php/psibernetika DOI: 10.30813/psibernetika.v13i1.2314 Hasil Penelitian

memonitor aktivitas mereka sedapat mungkin, ketika membuat aturan, mereka menjelaskan alasannya kepada anak. Mereka akan berkonsultasi dengan anak mengenai keputusan dan kebijakan tetapi jarang memberikan hukuman. Orang tua yang permisif memiliki kehangatan tetapi tidak mengontrol dan tidak menuntut anak mereka. Pola asuh permisif dibagi menjadi dua (Santrock, 2010) yaitu pola asuh permisif mengabaikan (neglectful parenting) dan pola asuh permisif memanjakan (indulgent parenting).

Gaya pengasuhan dimana orang tua sangat terlibat dalam kehidupan remaja tetapi sedikit tuntutan dan kendali kepada remaja. Orang tua yang memiliki pola asuh ini sangat memanjakan anaknya dan membiarkan remaja melakukan apapun yang diinginkan mereka. Hal ini berakibat mereka selalu menginginkan keinginan mereka untuk diikuti oleh orang tua. Orang tua yang permisif memanjakan adalah orangtua yang menghargai ekspresi diri dan pengaturan diri. Mereka membuat sedikit permintaan dan membiarkan remaja memonitor aktivitas mereka sendiri. Orangtua permisif memanjakan berkomunikasi dengan remaja mengenai aturan dan kebijakan tetapi jarang menghukum. Orangtua permisif memanjakan hangat pada remaja tetapi tidak mengontrol dan menuntut.

Pentingnya persepsi terhadap pola asuh disebabkan karena remaja saat ini mudah terpengaruh dengan pergaulan bebas yang beresiko.Pengaruh dari pergaulan seperti ini dapat mengarahkan mereka pada perilaku yang beresiko seperti perilaku seksual pranikah. Analisa World Health Organization (WHO) pada berbagai literatur kesehatan reproduksi dari seluruh dunia menyatakan bahwa pola asuh orang tua adalah merupakan faktor risiko perilaku seksual risiko berat (Hidayah \& Maryatun, 2013). Munculnya perilaku seksual pranikah disebabkan karena masa remaja merupakan awal perkembangan organ seksual. Pekembangan organ seksual ini diikuti tumbuhnya naluri seksual yang dapat mendorong seseorang ke dalam perilaku seksual (Nuandri \& Widayat, 2014). Selain itu, ketertarikan dengan lawan jenis menjadi tinggi. Sehingga perilaku seksual beresiko dapat muncul di usia remaja seperti perilaku seksual pranikah. Perilaku seksual adalah segala tingkah laku yang didorong oleh hasrat seksual, baik dengan lawan jenis (Nuandri \& Hidayat, 2014).

Gagnon dan Simon (dalam Nuandri \& Hidayat, 2014) membagi perilaku seksual dalam kaitannya dengan masalah sosial ke dalam tiga tipe antara lain tolerated sex variance (kontak anal-oral genital pasangan heteroseksual, masturbasi, dan premaritalextramarital intercourse), asocial sex variance (incest, child molestation, pemerkosaan, exhibitionism, dan voyeurism), dan structured sex variance (homoseksualitas, prostitusi, dan pornografi). Dari beberapa perilaku seksual yang beragam, maka penulis memfokuskan kepada premarital intercourse atau perilaku seks pranikah yang saat ini menjadi permasalahan sosial karena meningkatnya perilaku seks pranikah pada remaja.

Peningkatan data perilaku seksual pranikah juga dijelaskan dalam data terbaru Survei Indikator Kinerja Program Kependudukan dan KB Nasional tahun 2014 dari BKKBN menyatakan bahwa secara umum 5,6\% diantara remaja yang berpacaran pernah melakukan hubungan seksual. Angka ini lebih tinggi dibandingkan dengan tahun $2013(3,6 \%)$ dan tahun $2012(2,5 \%)$. Presentasi remaja wanita yang pernah melakukan hubungan seksual sebelum menikah relatif lebih rendah dari pada remaja pria $(2,8 \%$ berbanding 8,3\%). Berdasarkan jenis kelamin, pria yang pernah pacaran dan melakukan hubungan seksual sebelum menikah dengan presentasi tertinggi ditemukan pada provinsi Maluku dan Papua (masing-masing 33\%), Sulawesi Utara dan Papua Barat (masing-masing 28\%), dan Bali $(21 \%)$. Sedangkan pada jenis kelamin wanita yang melakukan hubungan seksual sebelum menikah dengan presentase tertinggi terdapat pada Provinsi Papua Barat (21\%), Papua (16\%), Sulawesi Utara (9\%), 
Versi Online: http://journal.ubm.ac.id/index.php/psibernetika DOI: 10.30813/psibernetika.v13i1.2314 Hasil Penelitian

dan Maluku (6\%) (BKKBN, 2014). Data perilaku seksual pranikah dari Komisi Nasional Perlindungan anak pada tahun 2014 yang melakukan penelitian terhadap perilaku seksual pada remaja SMP dan SMA, hasilnya menunjukkan bahwa $93,7 \%$ remaja pernah berciuman, petting, oral seksual, ada 62,7 remaja tidak perawan, $21,2 \%$ remaja SMA pernah aborsi, dan sebanyak $97 \%$ remaja pernah menonton film porno (Erlinda, 2014).

Berdasarkan data dari BKKBN Sulawesi Utara memiliki presentasi yang tinggi perilaku seksual pranikah. Selain itu, data dari penelitian sebelumnya yang berasal dari BKKBN (2010) di Provinsi Sulawesi Utara khususnya kota Manado, remaja yang melaporkan hamil diluar nikah atau kehamilan yang tidak diinginkan (KTD) tahun 2007 sebanyak 55 orang. Setahun kemudian melonjak hingga 254 orang atau naik 36\% dan tahun 2009 naik lagi menjadi 571 orang atau $78 \%$ (Sinaga \& Lampus,2015). Selain itu, hasil survei dari Dirjen Pengendalian dan Balai Teknik Kesehatan Lingkungan (BTKL) yang dilakukan pada tahun 2011 yang mengambil sampel 822 siswa SMA/SMK di Manado, sebanyak 112 diantaranya menyatakan pernah melakukan hubungan seksual 69 laki-laki dan 43 perempuan (“Seks bebas pelajar Sulut...", 2013).

Perilaku seksual pranikah pada remaja dapat menyebabkan remaja menghadapi resiko masalah kesehatan reproduksi.Setiap tahunnya 50.000 remaja di seluruh dunia meninggal karena kehamilan dan komplikasi persalinan ("Reproductive Health: Teen Pregnancy",2008; dalam Umaroh dkk,2015).Perilaku seksual pranikah memiliki dampak yang serius seperti aborsi.Angka aborsi di Indonesia terbilang cukup tinggi yakni mencapai 2,4 juta per tahun (Sarwono,2013).Terjadi peningkatan sekitar $15 \%$ setiap tahunnya, dan dari jumlah tersebut, 800.000 di antaranya dilakukan oleh remaja putri yang masih berstatus pelajar (BKKBN,2014).

Kasus Aborsi di Manado juga menjadi isu yang serius karena adanya
Jurnal Psibernetika

Vol.13 (No.1) : 32 -42. Th. 2020

p-ISSN: 1979-3707

e-ISSN: 2581-0871

kasus dokter yang menjadi tersangka asborsi ("Dokter di Manado tersangka aborsi", 2011). Selain itu berdasarkan keterangan dari PKBI (Perkumpulan Keluarga Berencana Indonesia), Sulawei Utara menyatakan bahwa kasus aborsi di Manado merupakan isu yang serius dan harus diperhatikan, tetapi sampai tahun 2016 belum ada instansi pemerintah, rumah sakit, klinik, dan instansi resmi lainnya, yang mau mempublikasiskan berapa banyak atau data aborsi di Manado ("Persoalan Aborsi di Sulut...",2016).Oleh karena itu, penelitian ini akan dilakukan kepada remaja di Manado karena adanya kasus kehamilan di luar nikah yang semakin meningkat di Manado.

Berdasarkan penjelasan dari data diatas menunjukan bahwa perilaku seksual pranikah merupakan masalah yang dihadapi remaja karena dapat menimbulkan dampak negatif bagi remaja.Menurut Sugianto (2011), sejak lebih dari satu dekade terakhir ini telah terjadi perubahan dalam pandangan dan perilaku seksual di kalangan remaja di Indonesia dan hasil penelitian telah menunjukan adanya perubahan pola pergaulan menjadi semakin bebas yang di dukung oleh fasilitas, sehingga aktivitas seksual mudah dilakukan, bahkan berlanjut menjadi hubungan seksual (Handayani \& Setyawan,2015). Maka dari itu, permasalahan ini tidak terlepas dari setiap remaja yang memiliki sikap yang positif dan negatif terhadap perilaku seksual pranikah.

Sikap adalah penilaian seseorang terhadap suatu stimulus atau objek, berupa perasaan mendukung atau memihak maupun tidak mendukung atau tidak memihak pada objek tersebut. Sikap mempunyai peranan penting terhadap perilaku seksual, dimana sikap terdiri dari 3 komponen, yakni kognitif, afektif, dan konatif (perilaku) (Azwar, 2013). Sikap menunjukan pengetahuan dan informasi yang dimiliki seseorang, bagaimana perasaaan yang dimiliki oleh seseorang, dan kecenderungan seseorang terhadap sesuatu objek yang mengarahkan seseorang pada sebuah perilaku. Berdasarkan hasil 
Versi Online: http://journal.ubm.ac.id/index.php/psibernetika DOI: 10.30813/psibernetika.v13i1.2314 Hasil Penelitian

penelitian sebelumnya dari Pawestri, Wardani, \& Sonna (2013) menyatakan bahwa sikap memiliki hubungan dengan perilaku seksual pranikah yang berarti semakin positif sikap yang dimiliki remaja maka semakin baik perilaku seksual pranikah.Sehingga sikap dapat memprediksi perilaku.Oleh karena itu, dalam penelitian ini akan melihat pada sikap terhadap perilaku seksual pranikah.

Pada penelitian sebelumnya tentang sikap terhadap perilaku seksual pranikah yang dilakukan di Semarang menunjukansikap siswa tentang seksual pranikah sebagian besar adalah negatif (tidak setuju) dengan perilaku seks pranikah yaitu sebanyak $(54,4 \%)$ (Parwesti, Wardani, \& Sonna, 2013). Selain itu penelitian yang dilakukan di SMA Negeri 1 Manado yang dilakukan dengan 96 responden menunjukan bahwa $99 \%$ atau 95 responden memiliki sikap yang negatif terhadap perilaku seksual pranikah yang berarti responden cenderung menghindari atau tidak setuju dengan perilaku seksual pranikah (Sinaga \& Lampus,2015). Tetapi peningkatan angka kasus perilaku seksual pranikah terus menerus meningkat.Sikap remaja terhadap perilaku seksual pranikah tidak lepas dari peran orang tua yang remaja rasakan melalui persepsi terhadap pola asuh.

Peneliti melakukan wawancara pada enam orang remaja yang bersekolah di SMAN X Manado untuk mendapatkan gambaran fenomena persepsi terhadap pola asuh orang tua dan sikap terhadap perilaku seksual pranikah.Hasil wawancara menunjukan empat dari enam remaja menyatakan sudah melakukan hubungan seksual pranikah dan lainnya masih belum melakukan hubungan seksual pranikah.Hal tersebut didaptkan dari keterangan pada saat wawancara.

"Pertama pas batona itu masih baku pegang tangan, baru so bacium, abis itu so mulai baraba, abis itu so baminta, kong so minta berhubungan badan.(Pertama saat
Vol.13 (No.1) : 32 -42. Th. 2020

p-ISSN: 1979-3707

e-ISSN: 2581-0871

pacaran masih
berpegangan tangan,
setelah itu ciuman, lalu
mulai meraba bagian
sensitif, setelah itu minta
pacar saya untuk
melakukan hubungan
badan) (Komunikasi
personal dengan NM, 2017.
"Pada saat SMA sudah mulai
belajar tingkah laku yang
tidak wajar.Kalau jujur saya
sudah sampai melakukan
hubungan badan, dan memulai
pada saat saya kelas 3 SMA
sekarang."(Komunikasi
personal dengan AP, 2017).
"Saya mulai pacaran saat
SMP, waktu itu masih sekedar
berpegangan tangan, tetapi
sekarang saat SMA, sayalebih
berani melakukan hubungan
badan" (Komunikasi personal
dengan JS, 2017).
"Kalau saya memang sudah
melakukan hubungan seksual
mulai usia 16 tahun".
(Komunikasi personal dengan
AT,2017).

Dari hasil wawancara bahwa enam remaja tidak mengetahui dampak dari perilaku seksual pranikah dan tidak memahami tentang pendidikan seksual. Tiga remaja yang sudah melakukan hubungan merasa biasa saja dengan hubungan seksual pranikah dan satu remaja merasa menyesal melakukan hubungan seksual pranikah yang seharusnya tidak dilakukan di usia remaja. Dua remaja yang belum melakukan hubungan seksual merasa tidak nyaman dengan perilaku seksual pranikah (Komunikasi Pribadi, 2017).

Peneliti juga menanyakan tentang hubungan dengan orang tua, tiga dari empat remaja yang sudah melakukan hubungan seksual pranikah menyatakan bahwa orang tua mereka adalah orang tua tidak terlalu memiliki waktu untuk mengawasi pergaulan mereka dan tidak pernah membicarakan tentang pergaulan dan 
Versi Online: http://journal.ubm.ac.id/index.php/psibernetika DOI: 10.30813/psibernetika.v13i1.2314 Hasil Penelitian

perilaku seksual pranikah pada remaja. Bahkan salah satu diantara mereka menyatakan bahwa orangtuanya terlalu memanjakan dirinya, sehingga dia memiliki kebebasan untuk mengikuti kemauannya. Sedangkan dua remaja yang belum melakukan hubungan seksual pranikah menyatakan orang tua mereka selalu menasehati dan mengontrol pergaulan mereka tetapi masih memberikan kesempatan untuk bergaul. Sehingga dua remaja ini merasa sangat terbantu dengan hal tersebut (Komunikasi Pribadi, 2017).

SMAN X Manado merupakan salah satu sekolah menengah atas yang berada di Provinsi Sulawesi Utara. SMAN X Manado yang didirikan pada tahun 1979 menjadi salah satu pilihan siswa/i di Manado untuk melanjutkan pendidikan di Sekolah Menengah Atas. SMAN X Manado dipilih oleh peneliti karena berdasarkan hasil keterangan dari empat siswa/i kelas XII yang diwawacara secara singkat oleh peneliti. Dua siswa menyatakan ada tiga teman mereka yang hamil diluar nikah pada kelas X. Selain itu pada dua siswa lainnya menyatakan bahwa ada teman mereka yang mengikuti ujian akhir sekolah setelah melahirkan karena hamil diluar nikah.

Selain melakukan wawancara singkat dengan siswa/i, peneliti juga melakukan wawancara dengan guru bimbingan konseling dan menyatakan bahwa selama tiga tahun terakhir sering terjadi kasus kehamilan pada siswa. Pada awalnya kasus seperti ini belum bisa terdeteksi oleh guru dan biasanya kasus ini sering terjadi menjelang ujian kelulusan untuk kelas XII. Guru bimbingan konseling menyatakan perilaku seksual pranikah yang semakin tinggi pada remaja saat ini memang tidak lepas dari peran orang tua yang dituntut untuk melindungi dan mengarahkan anak agar dapat menghindari perilaku seksual pranikah saat remaja. Guru bimbingan konseling juga menyatakan bahwa perilaku seksual pranikah merupakan bentuk protes dari remaja untuk orangtua. Selain itu, SMAN X Manado belum memberikan program pendidikan seksual secara khusus untuk siswa/i. Maka
Jurnal Psibernetika

Vol.13 (No.1) : 32 -42. Th. 2020

p-ISSN: 1979-3707

e-ISSN: 2581-0871

dari itu dari uraian masalah yang ada, penelitian ini bertujuan untuk mengetahui apakah ada hubungan antara Persepsi terhadap Pola Asuh Orang tua dan Sikap terhadap Perilaku Seksual Pranikah siswa/I SMAN 2 Manado.

\section{METODE PENELITIAN}

Penelitian ini merupakan penelitian kuantitatif dengan jenis penelitian korelasional. Teknik sampling yang digunakan dalam penelitian adalah purposive sampling yang merupakan pengambilan sampel secara random tetapi didasarkan pada tujuan tertentu (Sugiyono,2013). Kriteria sampel dalam penelitian adalah siswa/I dari SMAN X Manado yang tinggal dengan orangtua dan siswa dari kelas 10 sampai kelas 12. Jumlah sampel yang diperoleh sebanyak 220 siswa/i (87 orang laki-laki dan 133 orang perempuan).

Alat ukur persepsi terhadap pola asuh orangtua dibuat berdasarkan empat tipe pola asuh orangtua (Papalia \& Feldman, 2012; Santrock, 2010) yaitu: pola asuh otoriter, autoritatif, permisif memanjakan dan permisif mengabaikan. Jumlah aitem pada setiap tipe pola asuh sebanyak enam aitem, sehingga total jumlah aitem sebanyak 32 aitem. Peneliti melakukan uji coba alat ukur kepada 52 siswa-siswa, untuk mengetahui validitas dan reliabilitas alat ukur. Berdasarkan tabel Product moment, aitem-aitem dengan nilai Corrected Item- Total Correlation $<0.273$ dinyatakan gugur. Hasil uji coba diperoleh 18 aitem valid. Tipe pola asuh authoritarian sebanyak empat aitem, pola asuh autoritatif sebanyak tiga aitem, pola asuh permisif mengabaikan sebanyak enam aitem, dan pola asuh permisif memanjakan sebanyak lima aitem. Nilai reliabilitas alat ukur persepsi terhadap pola asuh orangtua sebesar 0.815 .

Pada alat ukur sikap terhadap perilaku seksual pranikah dibuat berdasarkan tiga aspek sikap yaitu aspek kognitif, afeksi dan konatif. Aspek kognitif 
Versi Online: http://journal.ubm.ac.id/index.php/psibernetika DOI: 10.30813/psibernetika.v13i1.2314 Hasil Penelitian

merupakan pengetahuan dan kepercayaan (belief) remaja tentang perilaku seksual pranikah. Aspek afeksi merujuk pada perasaan positif atau negatif mengenai perilaku seksual pranikah. Aspek konatif merupakan kecenderungan remaja terhadap perilaku seksual dan tindakan/ perilaku seksual pranikah itu sendiri. Jumlah aitem sebelum uji coba sebanyak 64 aitem. Setelah uji coba dengan batas nilai Corrected Item- Total Correlation $<0.273$ diperoleh 51 aitem valid dengan reliabilitas sebesar 0.948. Kedua instrumen ini disusun menggunakan skala likert yang digunakan untuk mengukur sikap, pendapat, dan persepsi seseorang atau kelompok tentang fenomena sosial (Sugiyono,2013). Instrumen ini terdiri dari aitem favorable dan unfavorable dengan empat pilihan jawaban yaitu Sangat Setuju (SS), Setuju (S), Tidak Setuju (TS), dan Sangat Tidak Setuju (STS).

Skor jawaban responden akan diolah dengan perbandingan nilai mean teoretik dan mean empirik untuk gambaran persepsi pola asuh dan sikap perilaku seksual. Analisis uji korelasi menggunakan uji korelasi Pearson untuk mengetahui hubungan kedua variabel.

\section{HASIL DAN PEMBAHASAN}

\section{Kategorisasi data}

Gambaran persepsi pola asuh dalam penelitian ini dengan membandingkan mean empirik dan mean teoritik setiap dimensi pola asuh. Jika mean empirik lebih besar dari mean teoritik artinya persepsi terhadap pola asuh tersebut cenderung tinggi dan jika mean empirik lebih kecil dari mean teoritik artinya persepsi terhadap pola asuh tersebut cenderung rendah. Hasil menunjukan bahwa sebagian bersar subjek mempersepsikan pola asuh autoritatif cenderung tinggi dibandingkan pola asuh lainnya.

Gambaran sikap terhadap perilaku seksual pranikah peneliti membandingkan mean empirik dan mean teoritik setiap dimensi pola asuh. Hasil menunjukan
Jurnal Psibernetika

Vol. 13 (No.1) : 32 -42. Th. 2020

p-ISSN: 1979-3707

e-ISSN: 2581-0871

subjek memiliki sikap terhadap perilaku seksual pranikah yang cenderung rendah.

Hasil uji korelasi persepsi pola asuh otoriter dengan sikap terhadap perilaku seksual pranikah menunjukkan nilai $\mathrm{p}=$ $0,153>0,05$, yang berarti tidak ada hubungan antara pola asuh otoriter dengan sikap terhadap perilaku seksual pranikah. Hubungan persepsi pola asuh autoritatif dengan sikap terhadap perilaku seksual pranikah menunjukkan nilai $\mathrm{p}=0,301>$ 0,05 yang artinya tidak ada hubungan antara pola asuh autoritatif terhadap perilaku seksual pranikah. Namun, pada hubungan persepsi pola asuh permisif mengabaikan terdapat hubungan signifikan terhadap sikap perilaku seksual pranikah, $(\mathrm{p}=0,000<0,01)$. Persepsi tentang pola asuh orangtua permisif memanjakan juga berhubungan signifikan dengan sikap terhadap perilaku seksual pranikah $(\mathrm{p}=0,001<0,01)$.

Tabel 1. Korelasi antar variabel

\begin{tabular}{lcc}
\hline Persepsi tentang & \multicolumn{2}{c}{$\begin{array}{c}\text { Sikap terhadap perilaku } \\
\text { Pola Asuh }\end{array}$} \\
\cline { 2 - 3 } Orangtua & $r$ & $p$ \\
\hline Otoriter & 0,097 & 0,153 \\
Autoritatif & $-0,070$ & 0,301 \\
Permisif & 0,498 & 0,000 \\
Mengabaikan & & \\
Permisif & 0,231 & 0,001 \\
Memanjakan & & \\
\hline
\end{tabular}

Secara umum, menurut Bjorklund \& Blasi (2012), pola asuh orang tua akan dapat membentuk sikap dan karakter anak. Dari hasil penelitian menunjukan nilai $\mathrm{p}=$ $0,153>0,05$ dan bahwa tidak ada hubungan yang signifikan antara persepsi pola asuh authoritarian dengan sikap terhdap perilaku seksual pranikah pada siswa/i SMAN 2 Manado. Berdasarkan teori Baumrind, pola asuh otoriter melibatkan kontrol dan kepatuhan yang harus dipenuhi oleh remaja (Papalia, Olds, \& Feldman, 2009). Pola asuh otoriter merupakan pola asuh yang menunjukkan orangtua membuat batasan dan kendali yang tegas terhadap remaja. Dalam pola asuh autoritarian orang tua membuat 
Versi Online: http://journal.ubm.ac.id/index.php/psibernetika DOI: 10.30813/psibernetika.v13i1.2314 Hasil Penelitian

komunikasi yang sedikit dan tertutup dengan remaja dapat mendorong remaja untuk mengetahui dengan cara mereka sendiri (Nursal, 2007). Menurut Natuna (2007) bahwa anak-anak dari keluarga pola asuh otoriter menunjukkan beberapa kesulitan tertentu dalam berperilaku. Mereka yang dibesarkan dalam keluarga otoriter cenderung kurang memperlihatkan rasa ingin tahu serta cenderung kurang bisa bergaul. Hal ini disebabkan oleh sikap orangtua yang terlalu keras dan membatasi rasa ingin tahu anak dengan menerapkan berbagai aturan yang apabila dilanggar akan mendapatkan hukuman (Jannah,2011). Oleh karena itu, dengan adanya batasan-batasan dan kendali yang besar dari orangtua di satu sisi membuat remaja memiliki sedikit ruang untuk mencoba hal yang baru termasuk atau melakukan keinginannya seperti perilaku seksual. Pada penelitian sebelumnya oleh Angelina dan Matulessy (2013) diperoleh hasil yang serupa pola asuh otoriter tidak berhubungan dengan perilaku seks bebas remaja SMK, pola asuh otoriter juga tidak berhubungan dengan kontrol diri. Penelitian yang dilakukan oleh Marsito dan Yudha (2011) menemukan pola asuh otoriter tidak berpengaruh terhadap persepsi perilaku seks bebas remaja karena pola asuh otoriter diperlukan untuk diterapkan pada remaja dalam hal nilai yang perlu diterapkan sedini mungkin secara konsisten dan komitmen oleh orangtua.

Hasil uji korelasi pada persepsi pola asuh autoritatif menunjukan milai $\mathrm{p}=$ $0,301>0,05$ yang berarti bahwa tidak terdapat hubungan antara persepsi pola asuh autoritatif dengan sikap terhadap perilaku seksual pranikah pada remaja. Pola asuh autoritatif adalah merupakan pola asuh yang menggambarkan orangtua yang memiliki kepercayaan pada kemampuan mereka mengarahkan remaja, orangtua juga menghormati keputusan remaja, pendapat dan kepribadian. Orangtua dengan pola asuh autoritatif menjelaskan pada remaja alasan dibalik batasan atau aturan yang dibuat mereka (Papalia, Olds, \& Feldman,2009). Orang tua yang menerapkan pola asuh authoritatif pada remaja dapat mengakibatkan remaja tersebut menjadi ketergantungan terhadap orangtuanya dan tidak bisa mengambil keputusan atau pun tindakan yang tepat untuk dirinya. Hal ini disebabkan karena banyaknya nasehat tentang perilakuperilaku yang menyimpang sehingga remaja ingin mengetahui lebih jauh mengenai apa pendapat orang tua melalui penjelasan mereka (Niron, Marni, \& Limbu, 2012).

Pada remaja yang diawasi orang tuanya akan menunda bahkan menghindari hubungan seksual sedangkan pada remaja tanpa pengawasan orang tua akan melakukan hubungan seksual pertama pada usia lebih dini (Nursal, 2008). Hal yang sama juga terjadi ketika orangtua yang mampu memberikan pemahaman mengenai perilaku seksual kepada remaja dan tidak menganggap hal tersebut sebagai hal yang tabu, maka remaja cenderung mengontrol perilaku seksnya itu sesuai dengan pemahaman yang diberikan orang tuanya. Hal ini terjadi karena pada dasarnya pendidikan seksual yang terbaik adalah yang diberikan oleh orang tua melalui pengetahuan maupun perilaku sehari-hari (Hidayah \& Maryatun, 2013). Orang tua yang menerapkan pola asuh autoritatif adalah pola asuh yang memprioritaskan kepentingan anak, akan tetapi tidak raguragu mengendalikan mereka (Niron, Marni, \& Limbu, 2012). Oleh karena itu, remaja yang orangtuanya bersifat autoritatif cenderung memiliki tanggung jawab dan kesadaran diri dan mencoba menghindari perilaku yang beresiko seperti perilaku seksual pranikah pada remaja. Penelitian sebelumnya oleh Kartika dan Budisetyani (2018) yang mana terdapat hubungan pola asuh demokratis dengan perilaku seksual pada remaja di Denpasar dan Badung dengan kekuatan korelasi lemah.

Uji korelasi persepsi terhadap pola asuh permisif mengabaikan dengan sikap terhadap perilaku seksual pranikah pada remaja, menunjukan bahwa nilai $\mathrm{p}=0,000<$ 0,01 yang berarti hipotesis alternatif diterima sehingga hasil menunjukkan bahwa terdapat hubungan yang signifikan antara persepsi terhadap pola asuh orangtua 
Versi Online: http://journal.ubm.ac.id/index.php/psibernetika DOI: 10.30813/psibernetika.v13i1.2314 Hasil Penelitian

permisif mengabaikan dengan sikap terhadap perilaku seksual pranikah. Selain hasil pengujian hipotesis nilai $r=0,498$ artinya memiliki korelasi yang cukup dan dapat dikatakan bahwa semakin tinggi remaja mempersepsikan orangtua mereka memiliki pola asuh permisif mengabaikan maka semakin tinggi sikap positif (setuju) terhadap perilaku seksual pranikah. Berdasarkan teori dari Bumrind menyatakan bahwa pola asuh permisif mengambarkan orangtua yang membuat remaja untuk memonitor kegiatan dan aktivitas mereka sendiri. Orangtua yang permisif jarang menghukum, dan tidak mengontrol. (Papalia, Olds, \& Feldman,2009). Pola asuh permisif mengabaikan menunjukan orangtua yang tidak memiliki kepedulian pada remaja (Santrock,2010). Pola asuh permisif mengabaikan dapat membuat remaja memiliki pengendalian diri yang buruk dan cenderung tidak menghindari perilaku yang bersiko seperti perilaku seksual pranikah pada remaja karena dalam pola asuh permisif mengabaikan remaja bebas melakukan apapun yang mereka inginkan dan tidak takut karena orangtua yang tidak menghukum dan mengontrol mereka. Sehingga remaja akan bebas melakukan segala kegiatannya tanpa mengetahui apakah yang dilakukannya itu baik atau buruk. Ada beberapa alasan mengapa orang tua menerapkan pola asuh permisif ini. Salah satunya yaitu orang tua terlalu sibuk dengan pekerjaannya sehingga mereka tidak memiliki kesempatan untuk memberikan perhatian kepada anaknya (Niron, Marni, \& Limbu, 2012).

Hubungan antara persepsi pola asuh permisif memanjakan dengan sikap terhadap perilaku seksual pranikah menunjukan nilai $\mathrm{p}=0,001<0,01$ yang berarti adanya hubungan yang signifikan antara persepsi pola asuh permisif memanjakan dengan sikap terhadap perilaku seksual pranikah. Sehingga, semakin tinggi remaja mempersepsikan pola asuh orangtua mereka adalah permisif memanjakan maka semakin tinggi juga sikap positif (setuju) terhadap perilaku
Jurnal Psibernetika

Vol.13 (No.1) : 32 -42. Th. 2020

p-ISSN: 1979-3707

e-ISSN: 2581-0871

seksual pranikah. Pola asuh permisif memanjakan menggambarkan keterlibatan yang besar dari orangtua tetapi sedikit menuntut dan mengendalikan remaja (Santrock, 2010). Sebagaimana pola asuh permisif mengabaikan, orangtua dengan pola asuh permisif memanjakan memberikan kebebasan dan mengijinkan remaja melakukan apa yang mereka inginkan dan akibatnya remaja tidak pernah belajar mengendalikan perilaku mereka (Santrock, 2010). Remaja yang menyalahgunakan kebebasan yang diberikan oleh orang tua akan memiliki kecenderungan yang lebih tinggi untuk melakukan perilaku seksual sedangkan remaja yang menganggap kebebasan yang diberikan sebagai suatu kesempatan untuk dapat mengembangkan diri dengan melakukan kegiatan-kegiatan yang bermakna serta melatih diri untuk mampu mengambil keputusan, maka akan lebih rendah untuk melakukan perilaku seksual (Niron, Marni, \& Limbu, 2012). Oleh karena itu, dapat disimpulkan pola asuh permisif mengabaikan dan permisif memanjakan akan meningkatkan resiko remaja melakukan perilaku seksual pranikah karena tidak adanya kontrol, batasan, dan tuntutan dari orangtua kepada remaja.

\section{SIMPULAN}

Berdasarkan hasil penelitian dan pembahasan, siswa/i SMAN 2 Manado mempersepsi pola asuh authoritatif lebih tinggi dibandingkan pola asuh lain. Sebagian siswa/i, memiliki sikap terhadap perilaku seksual pranikah yang positif. Berdasarkan hasil uji hipotesis, persepsi pola asuh autoritarian dan persepsi pola asuh autoritatif tidak memiliki hubungan yang signifikan dengan sikap terhadap perilaku seksual pranikah. Sedangkan persepsi pola asuh permisif mengabaikan dan memanjakan memiliki hubungan yang signifikan terhadap sikap perilaku seksual pranikah.

Penelitian selanjutnya diharapkan dapat meneliti lebih mendalam dengan 
Versi Online: http://journal.ubm.ac.id/index.php/psibernetika DOI: 10.30813/psibernetika.v13i1.2314 Hasil Penelitian

mengkaji pola asuh dari ayah dan ibu, identifikasi pekerjaan dari ayah dan ibu, serta kedekatan remaja dengan orangtua. Selain itu, penelitian selanjutnya dapat melihat faktor-faktor mediator lainnya yang mempengaruhi pola asuh orang tua dengan sikap terhadap perilaku seksual pranikah seperti kesadaran diri dan pengetahuan seksual.

\section{DAFTAR PUSTAKA}

Angelina, D. Y., \& Matulessy, A. (2013). Pola asuh otoriter dan perilaku seks bebas remaja SMK. Persona, Jurnal Psikologi Indonesia, 2(2), 173-182.

Azwar, S. (2013). Sikap manusia teori dan pengukurannya edisi 2. Yogyakarta : Pustaka Belajar

Bjorklund, D F., \& Blasi, C H. (2012). Child and adolesence an integrated approach. International Edition: Wadsworth Cengage Learning

BKKBN. (2014, Juni). Pemerintah melegalkan aborsi?. Diunduh dari http://bkkbn.go.id

Erlinda, (2014). Upaya peningkatan anak dari bahaya kekerasan dan eksploitasi. Jakarta: Komisi Perlindungan Anak Indonesia

Fataruba R., Purwatiningsih S., \& Wardani Y. (2009). Hubungan pola asuh dengan kejadian kekerasan terhadap anak usia sekolah (6-18 Tahun) di Kelurahan Dufa-Dufa Kecamatan Ternate Utara. Jurnal Kesehatan Masyarakat, 3(3), 168-173

Handayani, S., \& Seriawan, F. (2015). Hubungan pengetahuan dengan sikap seks pranikah pada siswa SMAN I Kandanghaur Indramayu. Jurnal Kesehatan Masyarakat, 1(2), 1-6

Hidayah, N F N., \& Maryatun. (2013). Hubungan antara pola asuh orang tua dengan perilaku seksual pranikah pada remaja di SMK Batik 1 Surakarta. Gaster, Jurnal Kesehatan, 10(2), 53-61

Hurlock, E B. (2000). Perkembangan Anak Edisi 6. Jakarta : Penerbit Erlangga
Jurnal Psibernetika

Vol. 13 (No.1) : 32 -42. Th. 2020

p-ISSN: 1979-3707

e-ISSN: 2581-0871

Jannah, H. (2011). Bentuk pola asuh orang tua dalam menanamkan perilaku moral pada anak usia dini di Kecamatan Ampek Angkek. Jurnal Pesona PAUD, 1,(1), 1-10.

Kartika, A.A.I. D., \& Budisetyani, I.G.A. P. W. (2018). Hubungan pola asuh demokratis dengan perilaku seksual pranikah pada remaja di Denpasar dan Badung, Jurnal Psikologi Udayana, 5(1), 63-71.

Niron, Y M., Marni., \& Limbu R. (2012). Hubungan antara pola asuh orang tua dengan perilaku seksial siswa SMA Negeri 3 Kota Kupang tahun 2012. Jurnal MKM, 7(1), 60-71

"Dokter di Manado Tersangka Aborsi". (2011, Mei). Diunduh dari http://www.google.co.id/amp/s/app. kompas.com/amp/nasional/read/201 1/05/20/22355122/Dokter.di.Manad o.Tersangka.Aborsi

"Persoalan Aborsi di Sulut Isu Serius yang Masih dalam Bingkai”. (2016, Juni). Diunduh dari http://sulutdaily.com/persoalanaborsi-di-sulut-isi-serius-yangmasih-dalam-bingkai/

Nuandri, V T., \& Widayat, I W. (2014). Hubungan antara sikap terhadap religiusitas dengan sikap terhadap kecenderungan perilak seks pranikah pada remaja akhir yang sedang berpacaran di Universitas Airlangga Surabaya. Jurnal Psikologi Kepribadian dan Sosial, 3(2), 60-69

Nursal, D G A. (2008). Faktor-Faktor yang Berhubungan dengan Perilaku Seksual Murid SMU Negeri di Kota Padang Tahun 2007. Jurnal kesehatan Masyarakat , 2(2), 175180

Papalia., Olds., \& Feldman. (2008). Human Development. Jakarta : Penerbit Salemba

Putri, B D. (2014). Peran faktor keluarga dan karakteristik remaja terhadap perilaku seksual pranikah. Jurnal Biometrika dan Kependudukan, 3(1), 8-19 
Safitri, Y., \& Hidayati, E. (2013). Hubungan antara pola asuh orang tua dengan tingkat depresi remaja di SMK 10 November Semarang. Jurnal Keperawatan Jiwa, 1(1), 1117

Santrock, J.W. (2010). Adolescense $13^{\text {ed }}$. International Edition: Mc- Graw Hill

Sarwono, S. (2013). Psikologi Remaja Edisi 16. Jakarta : PT. Raja Grafindo Persada

Sinaga, M., \& Kandou, G D. (2015). Gambaran perilaku remaja terhadap seks pranikah di SMA Negeri 1 Manado. Jurnal Kedokteran Komunitas dan Tropik, 3(1), 6-10

Sugiyono. (2013). Metode Penelitian Managemen. Bandung: Penerbit Alfabeta

Umaroh, A K., Kusumawati, Y., \& Kasjono, H B. (2015). Hubungan antara faktor internal dan faktor eksternal dengan perilaku seksual pranikah remaja di Indonesia. Jurnal Kesehatan Masyarakat, 9(1), 65-75

Wulaningsih, R., \& Hartini, N. (2015). Hubungan antara Persepsi Pola Asuh Orangtua dan Kontrol Diri Remaja terhadap Perilaku Merokok di Pondok Pesantren. Jurnal Psikologi Klinis dan Kesehatan Mental, 4(2), 119-126 